\title{
Bone mineral density in patients with multiple sclerosis
}

\author{
Chrissa Sioka1,2, Andreas Fotopoulos $^{1}$ \\ 'Department of Nuclear Medicine, University Hospital of loannina School of Medicine, loannina 45500, Greece. \\ ${ }^{2}$ Neurosurgical Institute, University of Ioannina School of Medicine, loannina 45500, Greece.
}

Correspondence to: Dr. Chrissa Sioka, Department of Nuclear Medicine, University Hospital of loannina, No. 1 Stavrou Niarchou St., Ioannina 45500, Greece. E-mail: csioka@yahoo.com

How to cite this article: Sioka C, Fotopoulos A. Bone mineral density in patients with multiple sclerosis. Neuroimmunol Neuroinflammation 2018;5:18. http://dx.doi.org/10.20517/2347-8659.2018.06

Received: 27 Feb 2018 First Decision: 13 Apr 2018 Revised: 18 Apr 2018 Accepted: 18 Apr 2018 Published: 22 May 2018

Science Editor: Athanassios P. Kyritsis Copy Editor: Guang-Zhe Zhu Production Editor: Cai-Hong Wang

Patients with multiple sclerosis (MS) have higher incidence of low bone mineral density (BMD) compared to normal subjects ${ }^{[1]}$. In their recent paper, Olsson et al. ${ }^{[2]}$ studied trabecular bone score (TBS) employing dual-energy X-ray absorptiometry (DXA) in lumbar spine (L2-L4), providing measurement of the bone microarchitecture. Their study was performed in 260 MS patients (202 being females) and compared with the results of 6310 healthy individuals taken from the TBS software database. Patients' mean age was 43 \pm 10 years (20-71) and control's group age was from 45 to 85 years old. The authors found that trabecular bone score was not altered in MS from the control population. They concluded that although BMD may be affected in MS patients, the bone microarchitecture seems to remain intact. However, an association was found with lower TBS and higher age, gender, expanded disability status scale (EDSS) $\geq 6$, disease duration, smoking and menopause.

The TBS is an assessment of bone quality correlated with bone microarchitecture and consists of an indicator for the risk of osteoporosis. It is actually a reflection of the structural condition of the bone microarchitecture.

This study had some limitations as reported by the authors. Due to the type of the study (retrospective/ cross-sectional), causality could not be determined and there was lack of medical information such as bone fractures, menarche age and lactation. Finally, the control group was not selected by the authors but was taken by the TBS software, where data is provided for individuals over 45 years old up to 85 years old that is problematic in comparison to a MS young to middle age peak demographic. 
Several risk factors for low BMD in MS patients have been reported such as, disease duration, total steroid dose, EDSS score (>3), immobility and vitamin D deficiency ${ }^{[3-7]}$. Vitamin D deficiency, especially during relapses, suggests that it could regulate clinical disease activity and it may be a modifiable MS risk factor. Vitamin D action is mediated through its specific receptor (VDR). Various polymorphisms of the VDR may affect vitamin $\mathrm{D}$ function and may be linked to osteoporosis and $\mathrm{MS}^{[8,9]}$.

Male MS patients exhibit reduced bone mass disproportionately to their age and ambulation ${ }^{[10]}$. Furthermore, reduced mobility and chronic low-dose glucocorticoid treatment in male MS patients is linked to increased osteoporosis and muscle wasting ${ }^{[11]}$. In premenopausal female patients, the length of the disease and their relative immobility were linked to low $\mathrm{BMD}^{[12]}$. In addition, menarche age $\geq 13$ years and breast feeding may be associated with reduced $\mathrm{BMD}^{[12]}$. Another predisposing factor leading to reduced BMD in MS females includes 25-OH-Vit D3 deficiency and secondary parathyroid hormone $(\mathrm{PTH})$ elevation ${ }^{[13]}$.

Overall, the study by Olsson et al. ${ }^{[2]}$ provides novel questions for the existence of bone loss in MS patients and the participation of bone microarchitecture in this process. It is clear that further studies are needed to elucidate the role of bone microarchitecture during bone loss, as evaluated with the TBS. Due to the limitation of the study ${ }^{[2]}$, several information could not be provided such as the association of TBS with the fertility history or gynecological factors. Considering the physiological bone loss after a certain age and the fact that $80 \%$ of the studying patients were females, it would have been interesting to see the role of TBS according to gynecological factors in pre- and post-menopausal status.

In conclusion, the etiology of BMD loss in MS patients is yet to be answered and future studies of larger number of patients would help further elucidate the etiology of bone loss and perhaps the participation of bone microarchitecture during this process.

\section{DECLARATIONS}

\section{Authors' contributions}

Conceived and wrote the manuscript: Sioka C

Reviewed and corrected the manuscript: Fotopoulos A

\section{Financial support and sponsorship}

None.

\section{Conflicts of interest}

There are no conflicts of interest.

\section{Patient consent}

Not applicable.

\section{Ethics approval}

Not applicable.

\section{Copyright}

(c) The Author(s) 2018.

\section{REFERENCES}

1. Sioka C, Papakonstantinou S, Fotopoulos A, Alamanos Y, Georgiou A, Tsouli S, Pelidou SH, Kyritsis AP, Kalef-Ezra J. Bone mineral density in ambulatory patients with multiple sclerosis. Neurol Sci 2011;32:819-24. 
2. Olsson A, Oturai AB, Sondergaard HB, Sellebjerg F, Oturai PS. Bone microarchitecture and bone mineral density in multiple sclerosis. Acta Neurol Scand 2018;137:363-9.

3. Huang Z, Qi Y, Du S, Chen G, Yan W. BMI levels with MS Bone mineral density levels in adults with multiple sclerosis: a metaanalysis. Int $J$ Neurosci 2015;125:904-12.

4. Kepczynska K, Zajda M, Lewandowski Z, Przedlacki J, Zakrzewska-Pniewska B. Bone metabolism and vitamin D status in patients with multiple sclerosis. Neurol Neurochir Pol 2016;50:251-7.

5. Zengin Karahan S, Boz C, Kilic S, Can Usta N, Ozmenoglu M, Altunayoglu Cakmak V, Gazioglu S. Lack of association between pulse steroid therapy and bone mineral density in patients with multiple sclerosis. Mult Scler Int 2016;2016:5794910.

6. Ayatollahi A, Mohajeri-Tehrani MR, Nafissi S. Factors affecting bone mineral density in multiple sclerosis patients. Iran J Neurol 2013; 12:19-22.

7. Coskun Benlidayi I, Basaran S, Evlice A, Erdem M, Demirkiran M. Prevalence and risk factors of low bone mineral density in patients with multiple sclerosis. Acta Clin Belg 2015;70:188-92.

8. Sioka C, Kyritsis AP, Fotopoulos A. Multiple sclerosis, osteoporosis, and vitamin D. J Neurol Sci 2009;287:1-6.

9. Sioka C, Papakonstantinou S, Markoula S, Gkartziou F, Georgiou A, Georgiou I, Pelidou SH, Kyritsis AP, Fotopoulos A. Vitamin D receptor gene polymorphisms in multiple sclerosis patients in northwest Greece. J Negat Results Biomed 2011;10:3.

10. Weinstock-Guttman B, Gallagher E, Baier M, Green L, Feichter J, Patrick K, Miller C, Wrest K, Ramanathan M. Risk of bone loss in men with multiple sclerosis. Mult Scler 2004;10:170-5.

11. Zikan V, Tyblova M, Raska I, Havrdova E, Luchavova M, Michalska D, Kubena AA. Bone mineral density and body composition in men with multiple sclerosis chronically treated with low-dose glucocorticoids. Physiol Res 2012;61:405-17.

12. Sioka C, Fotopoulos A, Papakonstantinou S, Georgiou A, Pelidou SH, Kyritsis AP, Kalef-Ezra JA. The effect of menarche age, parity and lactation on bone mineral density in premenopausal ambulatory multiple sclerosis patients. Mult Scler Relat Disord 2015;4:287-90.

13. Terzi T, Terzi M, Tander B, Canturk F, Onar M. Changes in bone mineral density and bone metabolism markers in premenopausal women with multiple sclerosis and the relationship to clinical variables. J Clin Neurosci 2010;17:1260-4. 